\title{
Self-Sensing Active Magnetic Bearings with Zero-Bias-Current Control
}

\author{
Yuki Kato Student Member (Tokyo Denki University, kato@seigyo.e.dendai.ac.jp) \\ Toshiya Yoshida Member (Tokyo Denki University, tyoshida@e.dendai.ac.jp) \\ Katsumi OhniwaＭember（Tokyo Denki University, ohniwa@e.dendai.ac.jp)
}

Keywords: magnetic bearing, self-sensing, sensorless, zero-bias, PWM amplifier

This paper proposes a self-sensing active magnetic bearing (AMB) with zero-bias-current control. One degree-of-freedom (DOF) of the rotor is controlled by a pair of electromagnets which are alternatively energized by the proposed PWM amplifier; zerobias-current control is achieved. In contrast, a sensing carrier voltage is applied to both windings simultaneously.

Figure 1 shows the proposed PWM amplifier for zero-biascurrent self-sensing AMBs. $L_{1}$ and $L_{2}$ are windings of electromagnets for one DOF of the rotor. This PWM amplifier consists of two dc-dc converters capable of bidirectional voltages; $S_{1}, D_{1}, S_{3}$ and $S_{4}$ are switching devices of the dc-dc converter for $L_{1}$, and $S_{2}, D_{2}, S_{3}$ and $\mathrm{S}_{4}$ are for $L_{2}$. These converters work alternatively.

In the proposed method, the switching ripple voltage is used as the position-sensing carrier. An LC resonant circuit is placed between these converters. This works so that the position-sensing carrier voltage generated by the one dc-dc converter for the one winding is transferred to the other winding. The resonant frequency is set at the position-sensing carrier frequency or the switching frequency. Consequently, the sensing carrier voltage is applied to both windings and then both windings' currents always include the rotor position information. Differential position-sensing with good linearly is available.

The linearity of the proposed position sensing is shown in Fig. 2. The actual displacement is measured by a reference sensor. In this experiment, the current reference $i^{*}$ is fixed so that the winding current is 0 or $0.4 \mathrm{~A}$. Although the position signal slightly shifts according to the winding current, the linearity is enough for AMB control. Figure 3 shows a step response of the system. The estimated position by the proposed method agrees well with the reference sensor output. By this experimental setup, the rotor can run at $45,000 \mathrm{~min}^{-1}$.

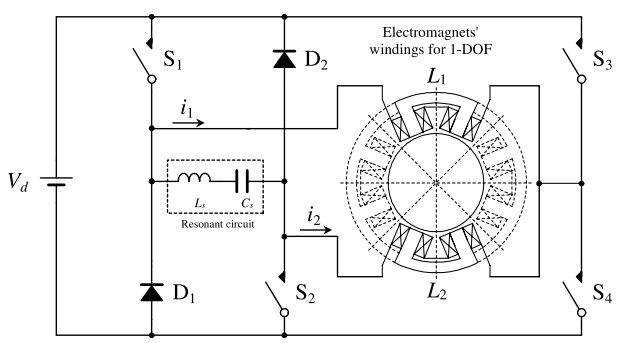

Fig. 1. The proposed PWM amplifier
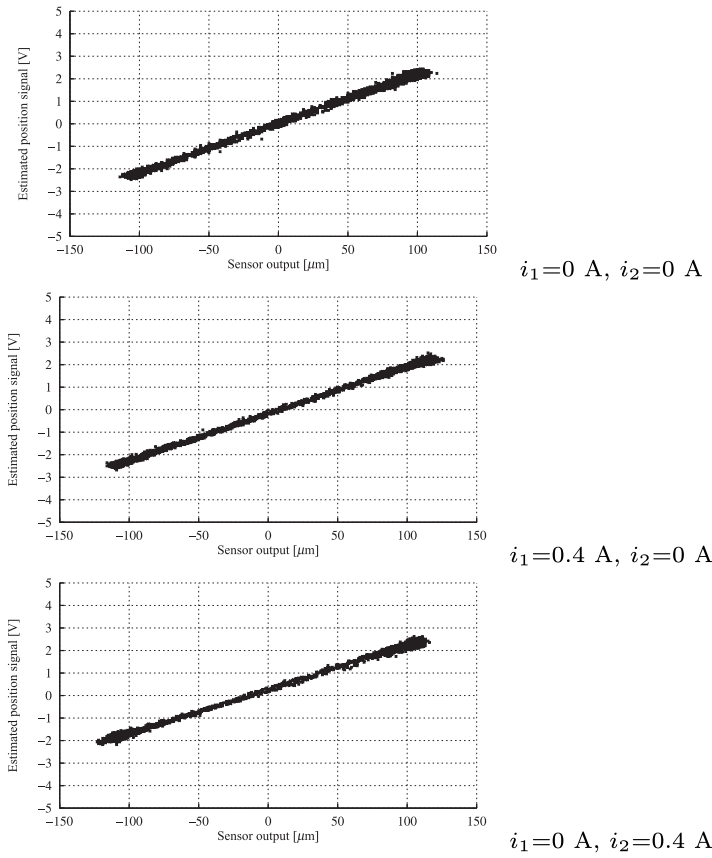

Fig. 2. Linearity of the estimated position signal

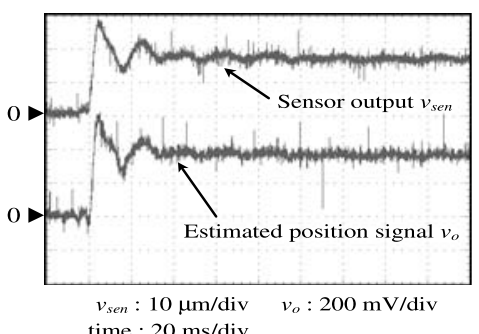

Fig. 3. Step response. 


\title{
ゼロバイアス電流方式によるセルフセンシング磁気軸受
}

\author{
学生員 加藤 友希* 正 員 吉田 俊哉* \\ 正 員 大庭 勝實*
}

\section{Self-Sensing Active Magnetic Bearings with Zero-Bias-Current Control}

Yuki Kato*, Student Member, Toshiya Yoshida*, Member, Katsumi Ohniwa*, Member

A zero-bias-current self-sensing active magnetic bearing is proposed. One degree-of-freedom (DOF) of the rotor is controlled by a pair of electromagnets which are alternatively energized by the proposed circuit. The rotor position of the one DOF is measured by using both electromagnets: the non-energized electromagnet also contributes to the position sensing. The proposed method gives good linearity in the position estimation. The controller of the magnetic levitation consists of a digital signal processor, DSP, which compensates the nonlinearity of the magnetic force and achieves good damping. In the experiment, the rotor can run at $45000 \mathrm{~min}^{-1}$.

キーワード : 磁気軸受, セルフセンシング, センサレス, ゼロバイアス, PWM アンプ

Keywords: magnetic bearing, self-sensing, sensorless, zero-bias, PWM amplifier

\section{1. まえがき}

常電導電磁石を用いた磁気軸受は, 非接触, 潤滑油不要 の有利性を生かし, 超高速回転機や宇宙空間, 真空中など の特殊環境下において使用され実績を上げている ${ }^{(1) \sim(3) 。 ~}$

元来，常電導電磁石を用いた磁気浮上系は不安定である ため, 浮上対象物の位置を検出し, 電磁石の電流または電圧 にフィードバック制御を施す必要がある。一般に実用され ている能動型磁気軸受 (AMB : Active Magnetic Bearing) においては電磁石と回転体のギャップ長を検出するために 変位センサを用いている。しかしながら，変位センサを用 いることで機器の小型化が難しく，またコストの増大が問 題となる。これらの問題を解決するために, 変位センサを 用いないセルフセンシング AMB (Self-Sensing AMB）が 各種提案されている(4) (9)。

セルフセンシング AMBでは, 回転体を支持するアクチュ エータである電磁石に変位センサとしての機能を併せ持た せ，電磁石の電気的応答を観測することにより変位を推定 する。一般的な AMB では，回転体の 1 自由度を支持する ために 2 つ電磁石を用いる。2つの電磁石は対向して設 置され, 電磁石間に回転体を置く。セルフセンシング方式 では, この 2 つ電磁石を両方用いて回転体の変位を差動検 出する。差動検出を行うことで線形な変位推定特性が得ら

\footnotetext{
* 東京電機大学大学院電気工学専攻

厂 101-8457 東京都千代田区神田錦町 2-2

Tokyo Denki University

2-2, Kanda-Nishiki-cho, Chiyoda-ku, Tokyo 101-8457
}

れ，実用性の高い AMB システムを構成することができる。 一方，対向する 2 つ電磁石に選択的に電流を流すゼロ バイアス電流方式による AMB が提案されている (10)(11)。多 くの AMB 制御では, 電磁石電流 (制御電流) と支持力（電 磁石吸引力）の関係を線形化するために電磁石巻線にバイ アス電流を流す。しかし，この電流は巻線における電力損 失や渦電流に起因するブレーキ作用による機械損失の原因 となる。ゼロバイアス電流方式ではバイアス電流を流さな いことでこれら損失の改善を図っている(11)。また，バイア ス電流を流さないことにより生じる電流と支持力の非線形 性は DSP (Digital Signal Processor) 等を用いて補償して いる。

ゼロバイアス電流方式においてもセルフセンシング化が 可能であれば，やはり小型化や，さらなるコストダウンが 図れ有用である。しかし, ゼロバイアス電流方式では対向 する電磁石を選択的に励磁するため, 同時に両電磁石の電 気的応答を観測することができない。すなわち变位の差動 検出が不可能である。1つの電磁石の応答から変位を推定 することは不可能ではないが, 変位推定特性における線形 性の問題や電磁石の励磁が切り替わる際に連続的な変位推 定が行えないなどの問題が生じる。このためゼロバイアス 電流方式のセルフセンシング化は容易ではなく，筆者の知 る限り別途励磁回路や励磁巻線を付加した方式 ${ }^{(12)}$ 以外では 見受けられない。

本論文ではゼロバイアス電流方式によるセルフセンシン グ $\mathrm{AMB}$ の新しい制御方式を提案する。この方式はゼロバ イアス電流制御を実現するために, PWM アンプにより対向 
する電磁石を選択的に励磁する回路構成としている。この 回路の特徵は両電磁石巻線間に新しく直列共振回路を配し ている点である。この共振回路は電磁石の電気的応答を計 測するために必要なキャリア信号を伝達する。これにより， 両電磁石が選択的に励磁された状態でもキャリア信号は両 電磁石に等しく供給され，変位の差動検出が可能となる。

実験では提案するゼロバイアス電流方式によるセルフセ ンシング $\mathrm{AMB}$ をターボ分子ポンプ用磁気軸受装置に適用 した。その結果，提案する方式に扔ける変位推定特性は十 分な直線性を示し，また電磁石の電流が共にほぼ流れてい ない状態や一方にしか流れていない状態においても良好な 変位推定ができることが確認された。さらに，実験機の定 格速度である $45000 \mathrm{~min}^{-1}$ でも安定な運転が可能であるこ とが確認された。本論文では提案するゼロバイアス電流方 式とバイアス電流を用いた方式(9)の損失について比較検討 するためにフリーラン試験を行った。その結果，ゼロバイ アス電流方式はバイアス電流を用いた方式に比べて機械損 失が少ないことが確認された。

\section{2. 磁気軸受のモデル}

図 1 は磁気軸受の 1 自由度分のモデルである。回転体の 1 自由度は選択的に動作する一対の電磁石によって制御さ れる(ゼロバイアス電流方式)。紙面向かって右側を回転体 の変位の正方向とする。また，回転体に作用する力は電磁 石 2 に近づけようとする方向を正とする。図 1 において， それぞれの電磁石が回転体に作用する力は

$$
\begin{aligned}
& -f_{1}=-k\left(\frac{i_{1}}{X_{0}+x}\right)^{2} \\
& f_{2}=k\left(\frac{i_{2}}{X_{0}-x}\right)^{2} \cdots
\end{aligned}
$$

で与えられる。但し， $k$ は定数， $X_{0}$ は定常ギャップ長， $x$ はギャップ長， $i_{1} ， i_{2}$ は卷線電流である。ゼロバイアス電 流方式における吸引力 $f$ は次式のように書ける。

$$
f=\left\{\begin{array}{rr}
-f_{1} & \left(i_{1}>0, i_{2}=0\right) \\
f_{2} & \left(i_{1}=0, i_{2}<0\right)
\end{array}\right.
$$

また, 電磁石 1 のインダクタンス $L_{1}$ と電磁石 2 のインダ クタンス $L_{2}$ は，漏れ磁束を無視するとそれぞれ，

$$
\begin{aligned}
& L_{1}=\frac{2 k}{X_{0}+x} \\
& L_{2}=\frac{2 k}{X_{0}-x}
\end{aligned}
$$

で与えられる。さらに (4)，(5)式より，両インダクタンス の逆数の差をとると

$$
x=k\left(\frac{1}{L_{1}}-\frac{1}{L_{2}}\right)
$$

なる関係が得られる。 $k$ は定数であることから両インダク タンスの逆数の差，またはサセプタンスの差はギャップ長 $x$ に対して線形であることがわかる。このように，両電磁

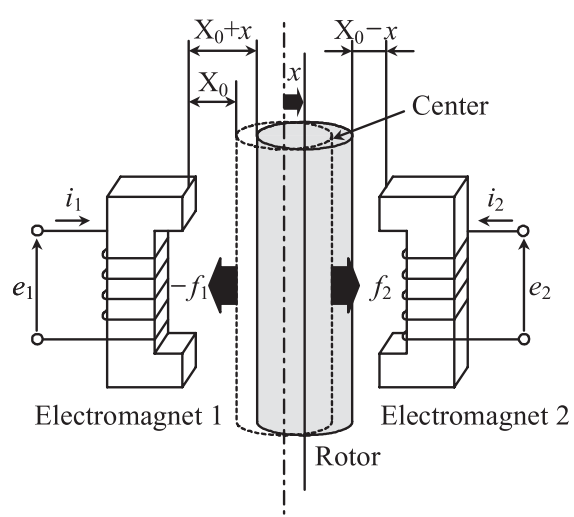

図 1 磁気軸受のモデル（1 自由度分）

Fig. 1. A model of a 1-DOF magnetic bearing.

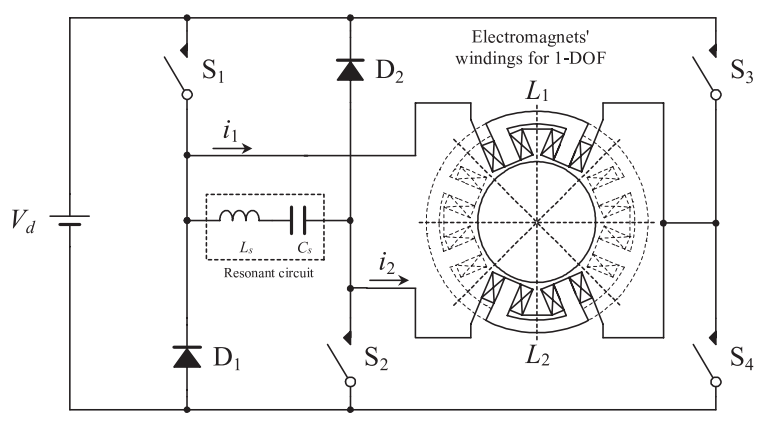

図 2 提案するPWM アンプ

Fig. 2. The proposed PWM amplifier.

表 1 PWM アンプのスイッチングモード

Table 1. Switching modes.

\begin{tabular}{c|c|c|c|c}
\hline & Mode I-1 & Mode I-2 & Mode II-1 & Mode II-2 \\
\hline $\mathrm{S}_{1}$ & ON & OFF & OFF & OFF \\
\hline $\mathrm{S}_{2}$ & OFF & OFF & ON & OFF \\
\hline $\mathrm{S}_{3}$ & OFF & ON & ON & OFF \\
\hline $\mathrm{S}_{4}$ & ON & OFF & OFF & ON \\
\hline $\mathrm{D}_{1}$ & OFF & ON & OFF & OFF \\
\hline $\mathrm{D}_{2}$ & OFF & OFF & OFF & ON
\end{tabular}

石のサセプタンスの差からギャップ長，すなわち変位情報 を得ることができる。実際には漏机磁束などにより，若干 の非線形性を示すが (6) 式のように差をとることで大幅に 線形化される。

\section{3. 提案する PWM アンプ}

図 2 はゼロバイアス電流方式においてセルフセンシング 化を実現する提案の PWM アンプ主回路である。図中の $L_{1}$ と $L_{2}$ は図 1 における電磁石巻線である。このPWM アン


なっており, 電磁石巻線に双方向に電圧を印加できる。 $S_{1}$, $\mathrm{D}_{1}, \mathrm{~S}_{3}, \mathrm{~S}_{4}$ は $L_{1}$ を, $\mathrm{D}_{2}, \mathrm{~S}_{2}, \mathrm{~S}_{3}, \mathrm{~S}_{4}$ は $L_{2}$ を駆動するため のスイッチング素子である。 $L_{1}, L_{2}$ が選択的に吸引力を発 生するようにスイッチングを制御することにより，ゼロバ イアス電流制御を実現する。適用されるスイッチングモー ドを表 1 に示す。モード I-1 とモード I-2 は $L_{1}$ を駆動する 
モードであり，モード II-1 とモード II-2 は $L_{2}$ を駆動する モードである。

提案する方式は PWM 制御により発生するスイッチング リプルをセンシングキャリアとして利用する(4)。しかし，支 持力を発生する電流は同時にはどちらか一方の電磁石にし か供給されないため，スイッチングリプルもどちらか一方 のみとなってしまう。そこで，本論文では両電磁石巻線間 に LC 直列共振回路を配することを提案する。共振回路の 共振周波数をキャリア周波数，すなわちスイッチング周波 数に設定する。これにより，共振回路は，スイッチングリ プル成分に対しては短絡状態となる。これは両電磁石巻線 が並列接続されていることと等価となるため，そのリプル 成分，すなわちセンシングキャリア電圧は両電磁石に等し く供給される。その結果，両電磁石の応答電流を常に計測 できるので，変位の差動検出が可能となる。

\section{4. システム}

〈4・1〉 システムのブロック図図 3 は提案するゼロ バイアス電流方式によるセルフセンシング $\mathrm{AMB}$ の 1 自由 度分のブロック図である。回転体の変位情報は電流差信号 $i_{1}-i_{2}$ に含まれる。電流差信号 $i_{1}-i_{2}$ のスイッチング周波 数周辺を帯域通過フィルタ（BPF1）により抽出する。抽出 した信号は増幅器 $k_{1}$, 高域通過フィルタ (HPF), 帯域通 過フィルタ（BPF2）を通して被検波信号 $\tilde{i_{f}}$ となる。被検 波信号 $\tilde{i_{f}}$ は検波回路に入力され，変位情報を得る。検波回 路は PWM 変調に用いる三角波キャリア信号に同期した同 期整流回路と低域通過フィル夕（LPF）により構成される。 検波回路の出力（変位推定信号） $v_{o}$ は制御器 $\left(G_{P I}\right.$ : 比例 ·
積分, $G_{P l d}$ : 一次進み補償) に入力される。制御器および, 電流と支持力の非線形を補償する補償器は DSP で実装さ れ, 電流指令值 $i^{*}$ を出力する。 $i^{*}$ が正の場合は $L_{1}$ が励磁さ れ， $i^{*}$ が負の場合には $L_{2}$ が励磁される。PWM 制御部には 巻線の 1 次遅れを補償するために巻線電流の和 $i_{1}+i_{2}$ に対 してフィードバックループ (比例ゲイン $\left.k_{2}\right)$ が形成されて いる。ゲートドライバは図 2 に示した PWM アンプの $\mathrm{S}_{1}$, $\mathrm{S}_{2}, \mathrm{~S}_{3}, \mathrm{~S}_{4}$ を駆動するためのゲート（スイッチング）信号 を生成する。なお， $\mathrm{S}_{3}, \mathrm{~S}_{4}$ に対しては常に互いに逆位相の ゲート信号を生成しているが， $\mathrm{S}_{1}, \mathrm{~S}_{2}$ に対しては電磁石巻 線の電流值によって選択的にゲート信号を生成する構成と なっている。

〈4·2〉 非線形補償 電磁石の吸引力は (1), (2) 式の ようにギャップ長と巻線電流の関数である。また，巻線電 流に対して非線形であるので，線形制御理論を適用するた めにはこれを補償する必要がある。(1)，(2)，(3) 式より電 流指令值 $i^{*}$ は,

$$
i^{*}=\left\{\begin{array}{l}
-\sqrt{\frac{f_{1}}{k}}\left(X_{0}+x\right) \\
=-\sqrt{\frac{-f}{k}}\left(X_{0}+x\right) \quad(f<0) \\
\sqrt{\frac{f_{2}}{k}}\left(X_{0}-x\right) \\
=\sqrt{\frac{f}{k}}\left(X_{0}-x\right) \quad(f \geq 0)
\end{array}\right.
$$

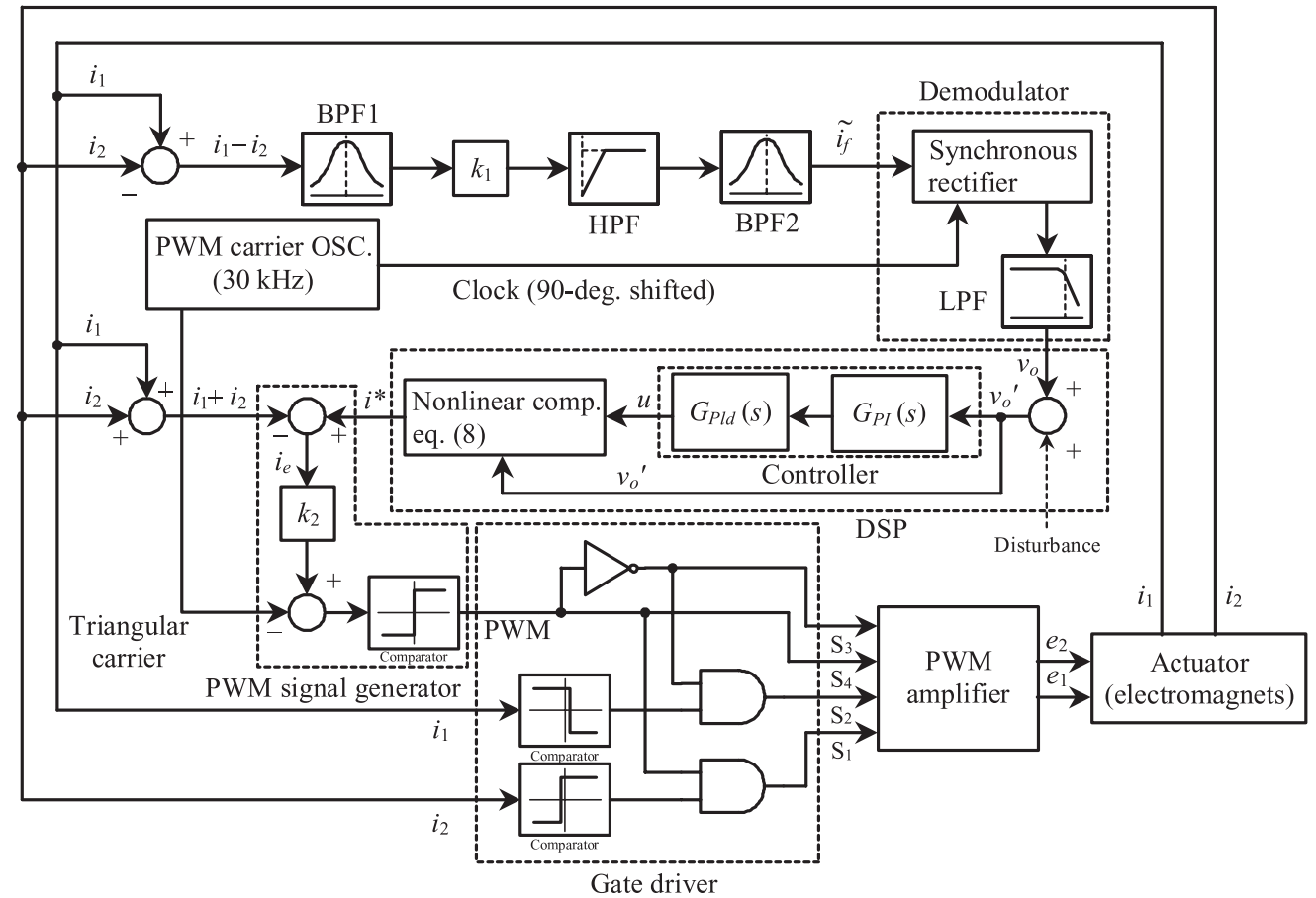

図 3 提案するセルフセンシング磁気軸受のブロック図（1 自由度分）

Fig. 3. A block diagram of the proposed self-sensing magnetic bearing (1-DOF). 
$i^{*}=\operatorname{sign}(f) k_{m}\left\{X_{0}-\operatorname{sign}(f) \cdot x\right\} \sqrt{|f|}$

となる ${ }^{(12)} \circ k_{m}(=1 / \sqrt{k})$ は定数, $\operatorname{sign}(\cdot)$ は引数の符号を 与える関数である。

\section{5. 実験結果}

〈5・1〉実験対象図 4 は実験に用いたターボ分子ポ ンプの軸受部である。実験では提案するゼロバイアス電流 方式によるセルフセンシング AMB をラジアル軸 2 自由度 (1X-1Y) に適用し，他の 3 つの自由度は文献(13) に報告



図 4 実験に用いたアクチュエー夕

Fig. 4. The actuator for the experiment.

表 2 PWM アンプおよび制御回路の主要パラメータ

Table 2. Parameters of the proposed PWM amplifier and control circuit.

\begin{tabular}{l|l}
\hline Switching frequency & $30 \mathrm{kHz}$ \\
\hline Supply voltage, $V_{d}$ & $30 \mathrm{~V}$ \\
\hline$L_{s}$ of resonant circuit & $1.46 \mathrm{mH}$ \\
\hline$C_{s}$ of resonant circuit & $19.1 \mathrm{nF}$ \\
\hline Passing bandwidth of BPF1 & $15 \mathrm{kHz}$ \\
\hline Passing bandwidth of BPF2 & $13 \mathrm{kHz}$ \\
\hline Cut-off frequency of LPF in demodulator & $2 \mathrm{kHz}$ \\
\hline
\end{tabular}

表 3 アクチュエータのパラメータ

Table 3. Parameters of the actuator.

\begin{tabular}{l|l}
\hline Nominal air gap, $X_{0}$ & $0.3 \mathrm{~mm}$ \\
\hline Nominal inductance of winding & $10 \mathrm{mH}$ \\
\hline Winding resistance & $2.7 \Omega$ \\
\hline Rotor mass & $1.3 \mathrm{~kg}$ \\
\hline
\end{tabular}

表 4 ケーブルの特性

Table 4. Characteristics of the cable.

\begin{tabular}{l|l}
\hline Cross section & $0.3 \mathrm{~mm}^{2}$ \\
\hline Resistance & $0.12 \Omega / \mathrm{m}$ \\
\hline Leakage conductance & $6.9 \times 10^{-7} \mathrm{~S} / \mathrm{m}$ \\
\hline Inductance & $0.75 \mu \mathrm{H} / \mathrm{m}$ \\
\hline Capacitance & $65 \mathrm{pF} / \mathrm{m}$ \\
\hline
\end{tabular}

されるセルフセンシング AMB によって支持される。なお， 提案するシステムの評価には AMB に併設されている誘導 型変位センサを使用した。実験パラメータを表 2 , 表 3 に 示す。また，電磁石と PWM アンプとのケーブル長（特性 は表 4) は $20 \mathrm{~m}$ とした。なお，制御器及び非線形補償器を 実装したDSP のサンプリング周波数は $20 \mathrm{kHz}$ とした。

$\langle\mathbf{5} \cdot 2\rangle$ 変位推定信号の直線性提案方式による推定 変位信号を図 5 に示す。横軸は評価用変位センサ出力, 縦 軸は提案する方式による推定変位信号である。図 5(a) は両 電磁石電流がほぼゼロのときで，(b)(c) は片側の電磁石に 0.4 A の電流（回転体の自重を支えるために必要な電流）を

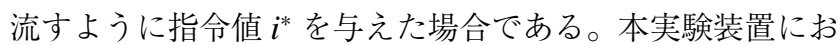

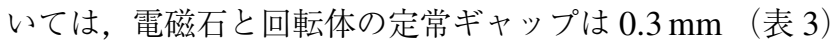
であるが，タッチダウンベアリングを装備しているため可 動範囲は $\pm 0.12 \mathrm{~mm}$ 程度となっている。図からわかるよう に，全可動範囲において十分な直線性が得られた。巻線電

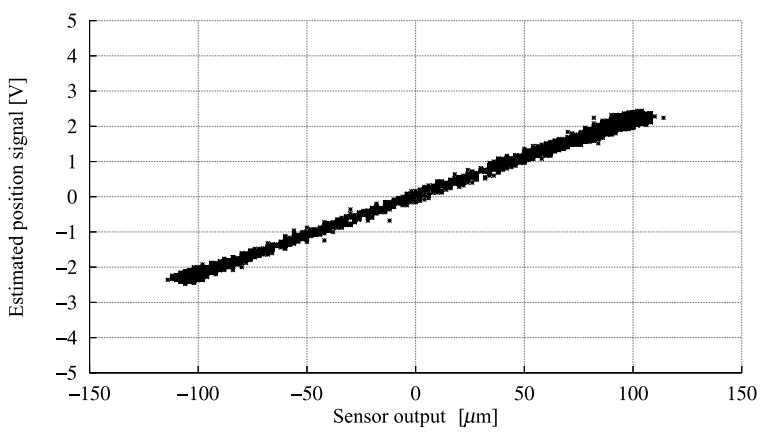

(a) $i_{1}=0 \mathrm{~A}, i_{2}=0 \mathrm{~A}$

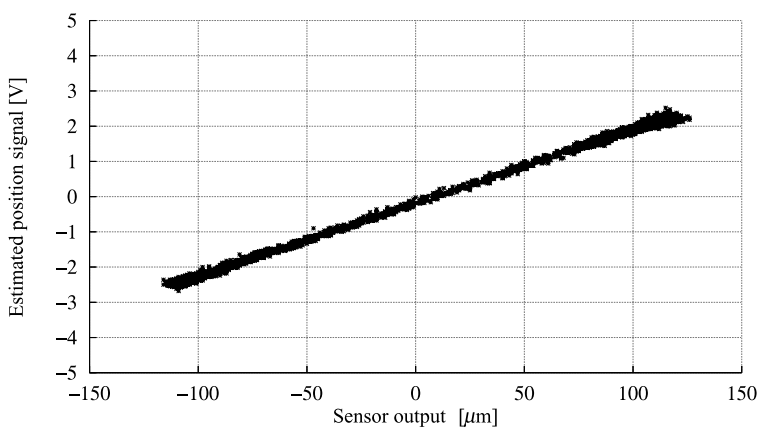

(b) $i_{1}=0.4 \mathrm{~A}, i_{2}=0 \mathrm{~A}$

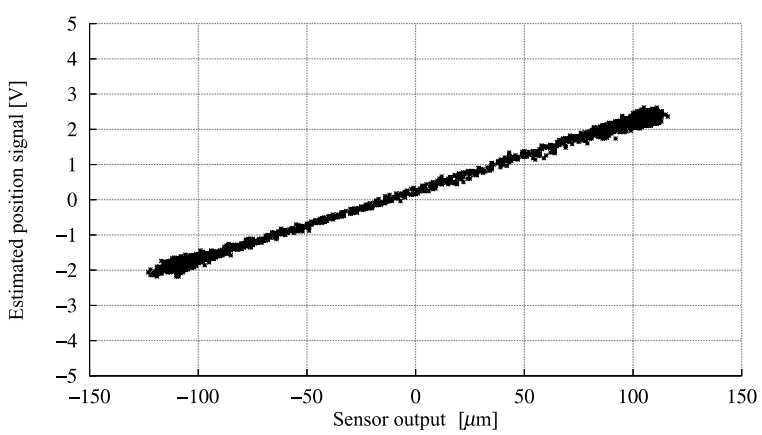

(c) $i_{1}=0 \mathrm{~A}, i_{2}=0.4 \mathrm{~A}$

図 5 変位推定信号の直線性

Fig. 5. Linearity of the estimated position signal. 
流によりオフセットが若干生じ，また感度もわずかに変化 するが，ターボ分子ポンプのように支持位置の精度を高く 要求しない用途においては問題ないと思われる。比較のた め, 図 2 に扔いて共振回路を取り去った場合の推定変位信 号を図 6 に示す。同図からわかるように，巻線電流がどち らか一方に流れているときは線形性が悪く, 巻線電流によ るオフセットも大きいことがわかる。これより，提案方式 の有用性が確認できる。

〈5・3〉 ステップ応答＼cjkstart図 7 は提案するシステムで回 転体を支持し，ステップ外乱を加えた時の応答である。ス テップ外乱は図 3 に扔ける “Disturbance”より与えた。提 案する方式による変位推定信号波形は, 評価用変位センサ の出力波形とほぼ相似形となっていることがわかる。これ より, 過渡状態においても変位推定が良好に行われている ことが確認された。

〈5・4 巻線電流波形図 8 は回転軸を垂直にした状 態での両電磁石巻線の電流波形である。また，図 9 は回転 軸を水平にした場合で，一方の電磁石により回転体の自重 を支持している状態である。電磁石と PWM アンプを結ぶ ケーブルの浮遊容量等の影響により双方の電流波形には大 きなリンギング電流が観測される。図 8 は外力のない状態

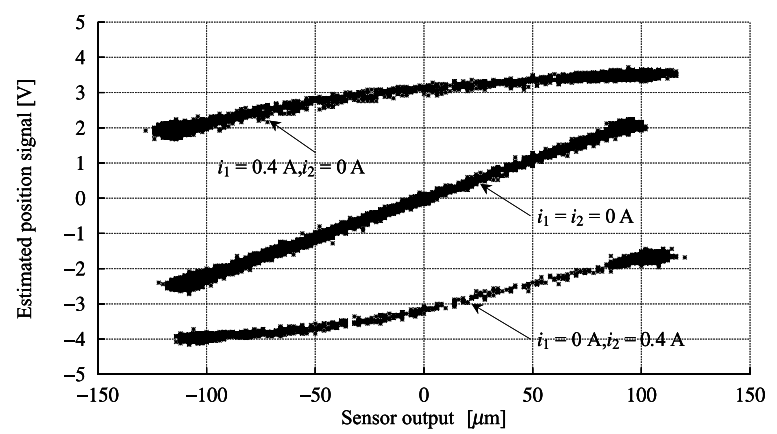

図 6 共振回路を取り除いた場合の変位推定信号

Fig. 6. The estimated position signal without the LC resonant circuit.

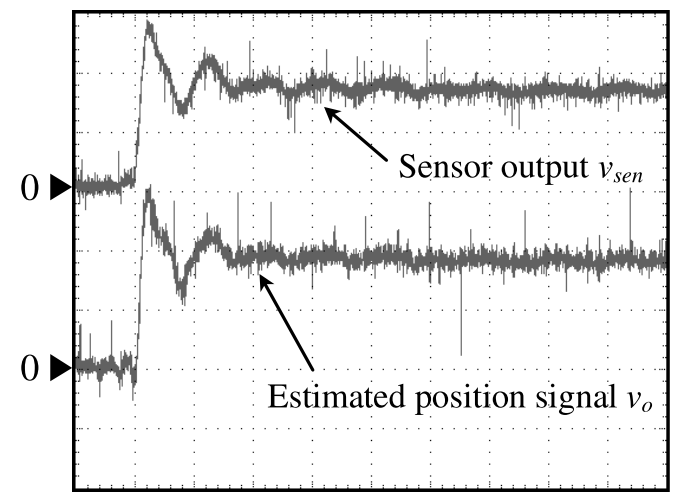

$v_{\text {sen }}: 10 \mu \mathrm{m} / \mathrm{div} \quad v_{o}: 200 \mathrm{mV} / \mathrm{div}$

time : $20 \mathrm{~ms} / \mathrm{div}$

図 7 ステップ応答

Fig. 7. Step response.
のため, 両電磁石の巻線電流はほぼゼロとなっているが, ス イッチングリプルは両方に確認できた。図 9 においては回 転体の自重を支持している一方の電磁石巻線にのみ大きな 電流が流れるが，支持力を発生していない電磁石の巻線電 流においてもスイッチングリプルを確認できた。

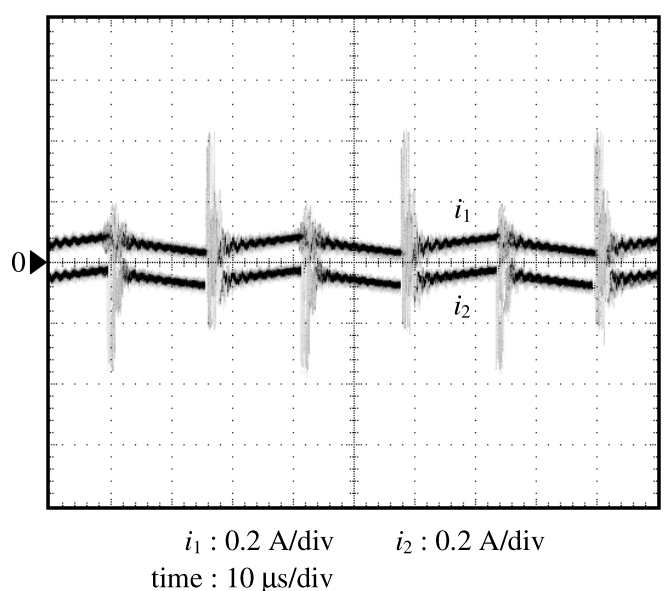

図 8 電磁石巻線電流波形（軸を垂直にした状態）

Fig. 8. Current waveforms (perpendicular).

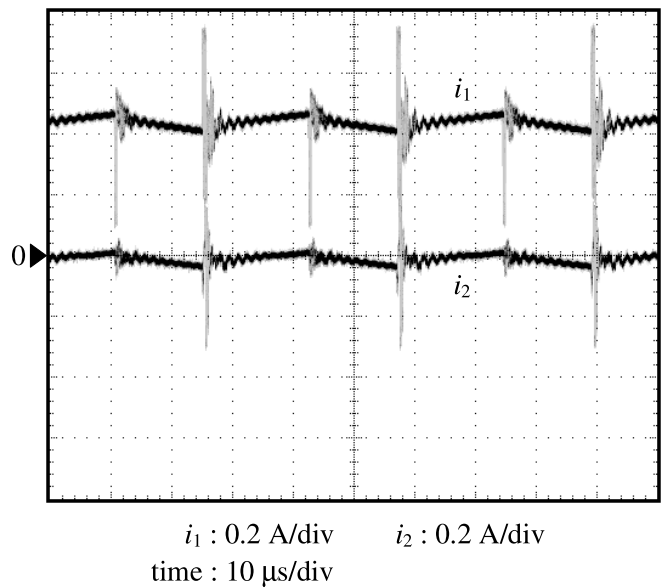

図 9 電磁石巻線電流波形（軸を水平にした状態）

Fig. 9. Current waveforms (horizontal).
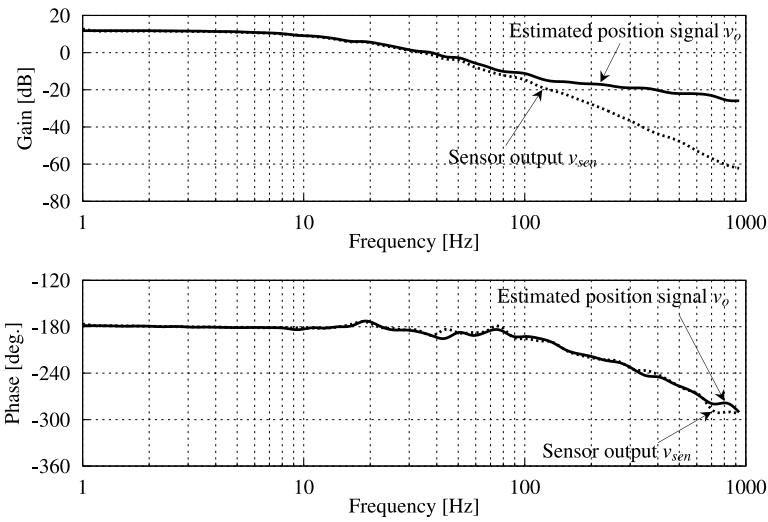

図 10 制御対象の周波数特性

Fig. 10. Frequency responses of the plant. 
$\langle\mathbf{5} \cdot \mathbf{5}\rangle$ 制御対象の周波数特性 図 10 は提案方式の変 位推定及び評価用変位センサによる制御対象の周波数特性 である。これらは図 3 の制御器出力 $u$ から変位推定出力 $v_{o}$ 及び評価用変位センサ出力 $v_{\text {sen }}$ までの伝達特性を計測した ものである。周波数特性測定用の外乱信号 (正弦波) は図 3 の “Disturbance”より加えた。変位推定出力 $v_{0}$ は変位セン サ出力 $v_{\text {sen }}$ と等しいことが望まれる。变位推定信号 $v_{o}$ は $80 \mathrm{~Hz}$ より高域ではセンサ出力 $v_{s e n}$ と比較してゲインの減 衰が鈍いが，低周波領域では一致しており良い特性を示し た。高域における減衰の鈍さは文献 (8) や (9) で述べられて いる実験結果と同じ傾向にある。これは磁路の非線形性が 原因で，回転体の変位だけでなく巻線電流によってもイン ダクタンスが変化し, 結果, 巻線電流が変位推定信号に干

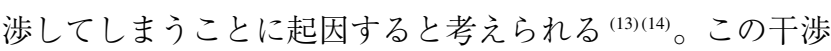
は, 磁気軸受系の応答が小さくなる高周波域において相対 的に大きくなるので，図 10 のように高域で誤差が顕著と なる。

〈5・6〉 速度減衰特性 図 11 はフリーラン時の回転速 度の減衰の様子を示したものである。ここでは, 5 自由度全 てを文献(13) の方式（バイアス電流を使用した 5 軸センサ レス磁気軸受) で浮上させるシステムと, 2 自由度 $(1 \mathrm{X}-1 \mathrm{Y})$ のみを提案するゼロバイアス電流方式で置き換えたシステ

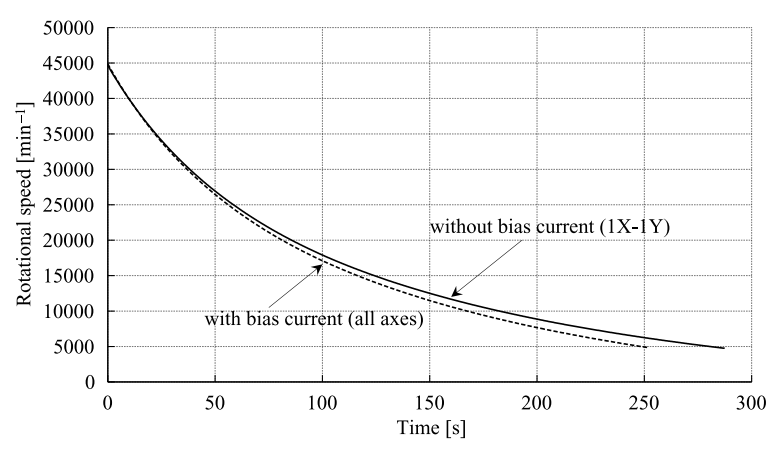

困 11 フリーラン試験

Fig. 11. Free run tests.

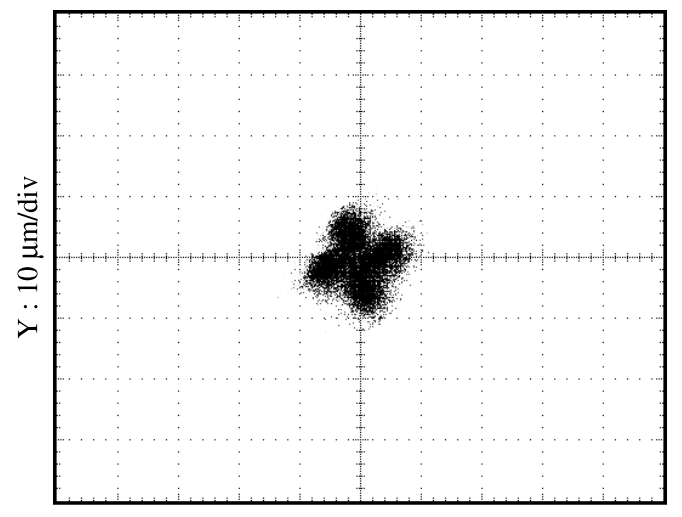

$\mathrm{X}: 10 \mu \mathrm{m} / \mathrm{div}$

図 12 回転体の変位の軌跡 (1X-1Y)

Fig. 12. A locus of the rotor (1X-1Y).
ムを比較した。なお, 実験は室内大気中で行い, バイアス 電流は $2 \mathrm{X}-2 \mathrm{Y}$ で $0.4 \mathrm{~A}, \mathrm{Z}$ で $0.6 \mathrm{~A}, 1 \mathrm{X}-1 \mathrm{Y}$ においてバイ アス電流を用いる場合は $0.4 \mathrm{~A}$ とした。

実験の結果, $45000 \mathrm{~min}^{-1}$ から $5000 \mathrm{~min}^{-1}$ までの減衰時 間は，全自由度にバイアス電流を用いた場合が $250 \mathrm{~s}, 2$ 自 由度 $(1 \mathrm{X}-1 \mathrm{Y})$ を提案方式に置き換えた場合が $280 \mathrm{~s}$ であっ た。2 自由度のみのゼロバイアス化ではあるが, 速度の減 衰が緩和され, 損失の低減が確認された。さらに他の自由 度にも提案する方式を適用すればさらなる損失の低減が可 能であると考えられる。

$\langle\mathbf{5} \cdot 7\rangle$ 回転体の軌跡図 12 は提案する方式で $1 X$ 軸, $1 \mathrm{Y}$ 軸を支持したときの $45000 \mathrm{~min}^{-1}$ における回転体の変 位の軌跡である。なお, 変位の軌跡の観測には評価用変位 センサを用いている。

通常, 変位のプロットを描くと円形になるが, 実験装置 においてはセンサに対向する回転体表面の不均一（ランナ ウト）のため 4 つ葉のクローバーのような形となっている。 しかしながら, 定格回転時における中心から振れは $10 \mu \mathrm{m}$ 以下であることが確認でき, 電磁石と回転体の定常ギャッ プ $(0.3 \mathrm{~mm})$ やタッチダウンベアリングとのギャップ (約 $0.12 \mathrm{~mm}$ ) に比べ十分小さいことが確認できる。

\section{6. むすび}

本論文ではゼロバイアス電流方式によるセルフセンシン グ AMB の新しい制御法について述べた。提案する方式の 変位推定信号は AMB の制御に十分な直線性を示した。さ らに, 実験機の定格速度である $45000 \mathrm{~min}^{-1}$ で安定な運転 が可能であることを確認した。提案のセンサレス方式によ り観測した制御対象の周波数特性は低周波領域では良い特 性を示した。

高域における変位推定特性の改善について，バイアス電 流を用いた方式については検討されているが(14), ゼロバイ アス電流方式について検討された報告は著者の知る限り見 当たらず，これについても今後，検討する必要がある。

最後に，本研究にあたって多くのご助言をいただきまし た東京電機大学理工学部電子情報工学科 宮下收教授に感謝 いたします。

(平成 18 年 3 月 1 日受付)

\section{文献}

（1）電気学会磁気浮上応用技術調査専門委員会編：「磁気浮上と磁気軸 受」, コロナ社 (1993)

（2）日本機械学会編：「磁気軸受の基礎と応用」, 養賢堂 (1995)

（3）我妻隆夫 ·金光陽一・高橋直彦・福島康雄・松下修己著：「回転機械 設計者のための磁気軸受ガイドブック」, 日本工業出版 (2004)

(4) K. Matsuda and Y. Okada: "Development of a Sensorless Magnetic Levitation Control System", Trans. of JSME (C), Vol.58, No.556, pp.247-251 (1992) (in Japanese)

松田健一・岡田養二 :「センサレス磁気浮上の研究」, 日本機械学論 (C 編), 58, 556, pp.247-251 (1992)

(5) D. Vischer and H. Bleuler: "Self-Sensing Active Magnetic Levitation", IEEE Trans. on Magnetics, Vol.29, No.2, pp.1276-1281 (1993) 
(6) K.K. Sivadasan: "Analysis of Self-Sensing Active Magnetic Bearings Working on Inductance Measurement Principle", IEEE Trans. on Magnetics, Vol.32, No.2, pp.329-334 (1996)

( 7 ) K. Matsuda, Y. Okada, and J. Tani: "Self-Sensing Magnetic Bearing Using the Differential Transformer Principle", Trans. of JMSE (C), Vol.63, No.609, pp.35-41 (1997) (in Japanese)

松田健一・岡田養二・谷 順二：「差動トランス方式セルフセンシン グ磁気軸受の研究」, 日本機械学論 (C 編), 63, 609, pp.35-41 (1997)

(8) S. Moriyama, K. Watanabe, and Y. Jouno: "Digital Control System for Sensorless Magnetic Bearings", Proc. of IEEJ IAS, Vol.3, pp.1379-1384 (2001) (in Japanese)

森山伸一・渡辺和英・城野義紀：「センサレス磁気軸受用デジタル 制御システム」, 平 13 電気学会産業応用部門大会, 3 巻, pp.1379-1384 (2001)

(9) T. Yoshida and K. Ohniwa: "A PWM Amplifier for Self-Sensing Active Magnetic Bearings with Low-sensitivity to Cable Length", IEEJ Trans. IA, Vol.123, No.10, pp.1206-1212 (2003-10) (in Japanese)

吉田俊哉・大庭勝實 :「ケーブル長変化の影響を受けにくいセルフセ ンシング磁気軸受用 PWM アンプ」, 電学論 D, 123, 10, pp.1206-1212 (2003-10)

(10) K. Sakai, K. Nonami, and Y. Ariga: "Low Consumption Nonlinear Control of Magnetic Bearing System by Means of Backstepping Procedure", Trans. of JSME (C), Vol.67, No.664, pp.68-73 (2001) (in Japanese)

酒井克章・野波健蔵・有我祐一：「バックステッピング法による磁 気軸受系の低消費電力型非線形制御」, 日本機械学論 $(\mathrm{C}), 67,664$ pp.68-73 (2001)

(11) P. Tsiotras, and B.C. Wilson: "Zero- and Low-Bias Control Designs for Active Magnetic Bearings", IEEE Trans. on Control Systems Technology, Vol.11, No.16, pp.889-903 (2003)

(12) M. Komori and C. Shiraishi: "A Levitated Motor with Superconducting Magnetic Bearings Assisted by Self-Sensing AMBs", IEEE Trans. on Appl. Superconductivity, Vol.13, No.2, pp.2189-2192 (2003)

(13) T. Yoshida, Y. Kuroba, K. Ohniwa, and O. Miyashita: "Self-Sensing Active Magnetic Bearings Using a New PWM Amplifier Equipped with a Bias Voltage Source", EPE Journal, Vol.15, No.2, pp.19-24 (2005)

(14) K. Morita, T. Yoshida, K. Ohniwa, and O. Miyashita: "Improvement of Position-Sensing Characteristics in Self-Sensing Active Magnetic Bearings", CD-ROM of EPE2O05

加 藤 友 希 (学生員) 1982 年 3 月 21 日生。 2004 年 4 月東

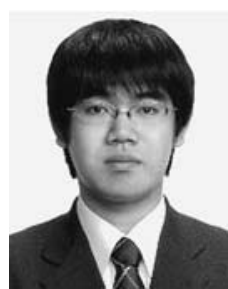
京電機大学工学部電気工学科卒業。同大学大学院 修士課程修了。現在，（株）大林組勤務。

吉 田 俊 哉 (正員) 1971 年 1 月 21 日生。1996 年 3 月東京

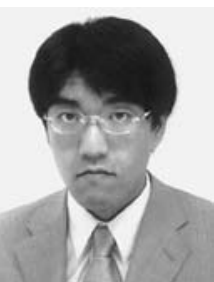
電機大学大学院理工学研究科応用電子工学専攻修 士課程修了。同年 4 月, 同大学理工学部応用電子 工学科助手, 2000 年 4 月, 同大学工学部電気工 学科助手, 2001 年 10 月, 同講師, 2004 年 10 月, 同助教授，現在に至る。博士 (工学)。制御機器 に関する研究に従事。IEEE 会員。EPE 会員。

大 庭 勝 實

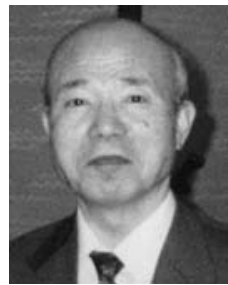

（正員） 1942 年 2 月 18 日生。1971 年 3 月東京 電機大学大学院工学研究科電気工学専攻博士課程 修了。1972 年 4 月, 同大学工学部講師, 1976 年 10 月，同助教授，1986 年 10 月，同教授，現在に 至る。工学博士。主として太陽光発電システム, 信号処理の研究に従事。 